\title{
Macroeconomic indicators as potential predictors of construction material prices.
}

\section{Indicadores macroeconómicos como posibles predictores de los precios de los materiales de construcción}

\author{
Diya K Dilip ${ }^{1}$, Jesna $\mathrm{N} \mathrm{M}^{2}$ \\ ${ }^{1}$ PG Student, ${ }^{2}$ Assistant Professor \\ Department of Civil Engineering \\ Toc $\mathrm{H}$ Institute of Science and Technology, Ernakulam (Kerala), India \\ Corresponding author mail id: diya.k.dilip@gmail.com, jesnanm@gmail.com
}

\begin{abstract}
The rate of construction materials is subjected to constant changes. The unexpected price changes affect the carrying-out rates of projects and even challenges the competence to finish the projects. The rapid and vast changes that occur all over the world in construction materials prices impacts the individual construction market value of each country. To avoid this problem, the contractor should have a tool or method that is capable to predict the future material prices. It is essential to predict the material prices variations during the implementation of the project as well as for preparing the tenders. Prediction of material price is an important function for effectively handling projects in terms of more exactly estimating, pursuing and monitoring projects. There are many tools that can help the construction contractors by its ability to accurately predict the future material price. Some of the methods normally used for prediction of materials prices are Artificial Neural Network, Fuzzy Logic, Statistical Method (includes regression analysis, MONTE CARLO method, ANOVA), and Trend Analysis. The type of predictors to these tools can be any factors that tend to have an impact on the prices of material. Macroeconomic indicators are one such factor that influences the prices of material as it reflects a country's economic status. This is a pilot study conducted in India to determine the possible macroeconomic indicators that influence the building material prices namely Portland cement and steel.
\end{abstract}

Keywords: Cost estimation, Artificial Neural Network, Macroeconomic indicator.

\section{RESUMEN}

La tasa de materiales de construcción está sujeta a cambios constantes. Los cambios inesperados de precios afectan las tasas de ejecución de los proyectos e incluso desafían la competencia para terminar los proyectos. Los rápidos y vastos cambios que 
Sustainability, Agri, Food and Environmental Research, (ISSN: 0719-3726), 10(X), 2022: http://dx.doi.org/

ocurren en todo el mundo en los precios de los materiales de construcción impactan el valor de mercado de la construcción individual de cada país. Para evitar este problema, el contratista debe tener una herramienta o método que sea capaz de predecir los precios futuros de los materiales. Es fundamental predecir las variaciones de precios de los materiales durante la ejecución del proyecto así como para la preparación de las licitaciones. La predicción del precio del material es una función importante para manejar proyectos de manera efectiva en términos de estimar, perseguir y monitorear proyectos con mayor precisión. Hay muchas herramientas que pueden ayudar a los contratistas de la construcción por su capacidad para predecir con precisión el precio futuro del material. Algunos de los métodos que se utilizan normalmente para predecir los precios de los materiales son la red neuronal artificial, la lógica difusa, el método estadístico (incluye análisis de regresión, el método MONTE CARLO, ANOVA) y el análisis de tendencias. El tipo de predictores de estas herramientas puede ser cualquier factor que tiende a tener un impacto en los precios del material. Los indicadores macroeconómicos son uno de esos factores que influyen en los precios de los materiales, ya que reflejan la situación económica de un país. Este es un estudio piloto realizado en India para determinar los posibles indicadores macroeconómicos que influyen en los precios de los materiales de construcción, a saber, cemento Portland y acero.

Palabras: clave-Estimación de costos, Red neuronal artificial, Indicador macroeconómico

\section{INTRODUCTION}

Macroeconomic indicators are a key part of fundamental analysis for traders, as they provide insight into the state of a country's economy. Macroeconomic indicators are statistics or data readings that reflect the economic circumstances of a particular country, region or sector. They are used by analysts and governments to assess the current and future health of the economy and financial markets.

Each country has its own specific macroeconomic indicators which is broadly categorised as explained below:

Leading indicators, which forecast where an economy might be heading. They are often used by governments to implement policies because they represent the first phase of a new economic cycle. These include the yield curve, interest rates and share prices.

Lagging indicators, which reflect an economy's historical performance and only change after a trend has been established. They are used to confirm a trend is underway. These include gross domestic product (GDP), inflation and employment figures.

There exists a category of coincident indicators, but these are generally grouped in 
Sustainability, Agri, Food and Environmental Research, (ISSN: 0719-3726), 10(X), 2022: http://dx.doi.org/

with lagging indicators as they either happen at the same time or after an economic shift. The economic indicators of India classified under various heads are as follows (Aithal, P. K. Dinesh. A. U., Geetha. M.)

- $\quad$ Markets - Currency, Government Bond10Y, Stock Market

- GDP - GDP, GDP Annual Growth Rate, GDP Constant Prices, GDP From Agriculture, GDP From Construction, GDP From Manufacturing, GDP From Mining, GDP From Public Administration, GDP From Utilities, GDP Growth Rate, GDP Per Capita, GDP Per Capita PPP, Gross Fixed Capital Formation, Gross National Product

- Labour - Employment Rate, Labour Force Participation Rate, Minimum Wages, Population, Retirement, Age Men, Retirement Age Women, Unemployment Rate, Youth Unemployment Rate

- $\quad$ Prices - Consumer Price Index CPI, Cpi Housing Utilities, CPI Transportation, Export Prices, Food, Inflation, GDP Deflator, Import Prices, Inflation Expectations, Inflation Rate, Producer Prices, Producer Prices Change

- $\quad$ Money - Cash Reserve Ratio, Central Bank Balance Sheet, Foreign Exchange Reserves, Interbank Rate, Interest Rate, Loan Growth, Money Supply M1, Money Supply M2, Money Supply M3, Reverse Repo Rate

- $\quad$ Trade - Auto Exports, Balance Of Trade, Capital Flows, Crude Oil Production, Current Account, Current Account To GDP, Exports, Exports By Category, Exports By Country, External Debt, Foreign Direct Investment, Gold Reserves, Imports, Imports By Category, Imports By Country, Remittances, Terms Of Trade, Terrorism Index, Tourism Revenues, Tourist Arrivals, Weapons Sales

- Government - Credit Rating, Fiscal Expenditure, Government Budget, Government Budget Value, Government Debt To GDP, Government Revenues, Government Spending, Government Spending To GDP, Holidays, Military Expenditure

- Business - Business Confidence, Capacity Utilization, Car Production, Car Registrations, Changes In Inventories, Competitiveness Index, Competitiveness Rank, Composite PMI, Corruption Rank, Deposit Growth, Ease Of Doing Business, Electricity Production, Industrial Production, Internet Speed, IP Addresses, Manufacturing PMI, Manufacturing Production, Mining Production, Services PMI, Steel Production, Total Vehicle Sales

- Consumer - Bank Lending Rate, Consumer Confidence, Consumer Spending, Disposable Personal Income, Gasoline Prices, Households Debt To GDP

- Housing - Construction Output, Housing Index 
Sustainability, Agri, Food and Environmental Research, (ISSN: 0719-3726), 10(X), 2022: http://dx.doi.org/

- $\quad$ Taxes - Corporate Tax Rate, Personal Income Tax Rate, Sales Tax Rate, Social Security Rate, Social Security Rate for Companies, Social Security Rate For Employees - Health - Coronavirus Cases, Coronavirus Deaths, Coronavirus Recovered, Hospital Beds

Asamoah R O et al, (2019), stated that, of the several factors influencing the cost of the building frequent changes in macroeconomic variables plays an important role. The study adopted the qualitative research approach; purposive and snowballing techniques for selecting respondents. The study revealed that respondents were satisfied with cost management procedures and practices and mainly relied on cash flow, progress reporting, and project cost control methods as means of monitoring and managing project cost. Relative important index, prime rate, interest rate, and inflation were some of the macroeconomic components that professionals considered having impact on cost. The respondents also recommended further studies on the impact of macroeconomic variability on cost of public buildings.

Ashuri B et al, (2012), studied about Construction Cost Index (CCI) and found that CCI has widely been used for cost estimation, bid preparation and investment planning. Cost estimators and investment planners are not only interested in the current CCI, but also are interested in forecasting changes in CCI trends. An important step towards forecasting CCI trends is to identify its leading indicators. The results of Granger causality tests show that consumer price index, crude oil price, producer price index, GDP, employment levels in construction, number of building permits, number of housing starts and money supply are the leading indicators of CCI. The results of Johansen's cointegration tests show that money supply and crude oil price are the leading indicators with long-term relationships with CCI. Chen $\mathrm{H}$ L et al, (2010), studied that though events in the macroeconomy significantly affect the construction market, most published studies on construction sales forecasts using Scurve models are unable to account for the economic climate. This study proposed an approach that employs financial and macroeconomic indicators to forecast sales of large development and construction corporations.

\section{MATERIALS AND METHODS}

The methodology adopted in the study is as follows:

\section{Selection of area of research and Literature Review}

The research problem was identified and the information required for the progress of study was obtained from the relevant literatures.

2. Data collection

The macroeconomic indicators are to be identified from the literature. The past 10 -year monthly variation of the prices of materials namely Portland cement of grade 53 and 
Sustainability, Agri, Food and Environmental Research, (ISSN: 0719-3726), 10(X), 2022: http://dx.doi.org/

reinforcing steel (Fe500 TMT bars) are obtained from reliable sources at Ernakulam region. For the prediction, the monthly prices of materials for the past 10 year has been used. Therefore, only those indicators having monthly frequency can be used as the predictors. Macroeconomic indicator selection is also dependent upon the data availability (Shiha, A. Dorra, E.M. and Nassar, k. 2020). These two factors constraints the selection of indicators. Since there are no studies made on the macroeconomic indicators effecting the construction in India till date, the indicators used in the study were identified from the data obtained and their relevancy keeping the study done by Ahmed Shiha (Pewdum, W. Rujirayanyong, T. and Sooksatra, V. 2009) in Egypt as reference. The indicators shortlisted are 9 macroeconomic indicators namely Producer Price Index (PPI), Construction output, Foreign Exchange Rate, Consumer Price Index (CPI), Inflation Rate, Bank Lending Rate, Foreign Direct Investment, Housing Utilities and Steel Production.

The monthly prices are obtained from construction projects in Ernakulam region located at Kerala, India which is taken in the time period from the month June 2010 to June 2020.

\section{Selection of Potential Leading Indicators}

Statistical correlation tests are done at this stage so as to find the indicators that is correlated with the prices. Correlation coefficients of both Pearson's and Spearman correlation with time lag investigation for $0,1,3,6$ and 12 months done with the aid of Microsoft Excel. Time lag investigation is done so as to have enough time ahead of prediction as well as to find the time period which lends greater correlation coefficients. Multicollinearity is tested within the indicators so as to avoid duplication by eliminating variables that show high Variation Inflation Factor (VIF). Then the indicators having high correlation with the prices is selected after stepwise regression analysis to obtain the best model.

\section{RESULTS AND DISCUSSIONS}

Correlation Coefficients: Correlation analysis was done between the 9 macroeconomic indicators with cement and steel prices. Pearson correlation test was done initially, using excel software. Pearson's correlation coefficients have a value ranging between -1 and +1 . Asuero et.al (2006) gave a spectrum to interpret the values of correlation coefficients. Results shows that PPI, Bank Lending Rate, Housing utilities, CPI and steel production share "high correlation" correlation with cement prices and steel prices. It is also detected that there is a "little" linear correlation between the remaining indicators. The best correlation is obtained when indicators are lagged 6 months. Table 1 and 2 summarizes the results of Pearson's correlation tests between each macroeconomic indicator with cement prices and steel prices respectively. The indicators which displayed "little" correlation (Asuero, A. G. Sayago, A. \& González. A. G 2006) is tested for spearman's correlation for checking their potentiality as predictors. 
Sustainability, Agri, Food and Environmental Research, (ISSN: 0719-3726), 10(X), 2022: http://dx.doi.org/

Table 1: Results of Pearson's correlation coefficient for cement with Macroeconomic Indicators Pearson correlation coefficient - CEMENT

\begin{tabular}{lccccc}
\hline INDICATOR & 0-month lag & 1-month lag & 3-month lag & 6 -month lag & 12-month lag \\
Producer Price Index & -0.5584 & -0.6196 & -0.7041 & -0.7261 & -0.5951 \\
Construction Output & 0.1152 & 0.0820 & 0.1067 & 0.0107 & -0.0766 \\
Foreign Exchange Rate & -0.1283 & -0.1251 & -0.0972 & -0.0388 & 0.0166 \\
Consumer Price Index & -0.3442 & -0.4070 & -0.5601 & -0.6688 & -0.6529 \\
Inflation Rate & 0.1037 & 0.1493 & 0.2366 & 0.3451 & 0.4945 \\
Bank Lending Rate & 0.1543 & 0.2283 & 0.4639 & 0.8031 & 0.7022 \\
Foreign Direct Investment & 0.0261 & -0.0313 & 0.1134 & -0.0242 & 0.1460 \\
Housing Utilities & -0.4246 & -0.4845 & -0.6275 & -0.7576 & -0.6157 \\
Steel Production & -0.4871 & -0.5763 & -0.7089 & -0.7882 & -0.6925
\end{tabular}

Spearman's correlation test was done for the remaining indicators in Excel itself using the formula [11]:

$$
r_{r}=1-\frac{6 \Sigma_{i} d_{i}}{n\left(n^{2}-1\right)}
$$

where $\mathrm{n}$ is the number of data points of the two variables and $d_{i}$ is the difference in the ranks of the $\mathrm{i}^{\text {th }}$ element of each random variable considered. Analysis results show that inflation rate has "moderate" correlation with cement prices. Thus, all indicators that has weak correlation with prices are eliminated. Table 3 and 4 shows the results of Spearman's correlation test.

Table 2: Results of Pearson's correlation coefficient for Steel with Macroeconomic Indicators Pearson correlation coefficient - STEEL

\begin{tabular}{lccccc}
\hline INDICATOR & 0-month lag & 1-month lag & 3-month lag & 6-month lag & 12-month lag \\
Producer Price Index & 0.8595 & 0.8553 & 0.8614 & 0.8307 & 0.6991 \\
Construction Output & -0.2388 & -0.2207 & -0.1698 & -0.0499 & 0.0686 \\
Foreign Exchange Rate & 0.1357 & 0.1082 & 0.0800 & 0.0688 & 0.0896 \\
Consumer Price Index & 0.7606 & 0.7612 & 0.7767 & 0.7783 & 0.7723 \\
Inflation Rate & -0.1507 & -0.1590 & -0.1044 & -0.0932 & -0.2970 \\
Bank Lending Rate & -0.7111 & -0.7236 & -0.7893 & -0.7526 & -0.8503 \\
Foreign Direct Investment & -0.0702 & -0.0661 & 0.1024 & 0.0697 & -0.0147 \\
Housing Utilities & 0.8467 & 0.8415 & 0.8388 & 0.8225 & 0.7618 \\
Steel Production & 0.3736 & 0.4030 & 0.4934 & 0.7889 & 0.6891
\end{tabular}

Table 3: Spearman's correlation coefficient for cement with Macroeconomic Indicators Spearman's correlation coefficient - CEMENT

\begin{tabular}{|c|c|c|c|c|c|}
\hline INDICATOR & 0-month lag & $\begin{array}{l}\text { 1-month } \\
\text { lag }\end{array}$ & 3-month lag & $\begin{array}{l}\text { 6-month } \\
\text { lag }\end{array}$ & 12-month lag \\
\hline Construction Output & 0.2710 & 0.2289 & 0.0768 & -0.1061 & -0.0900 \\
\hline Foreign Exchange Rate & -0.2778 & -0.2759 & -0.2413 & -0.1197 & 0.1166 \\
\hline Inflation Rate & 0.1236 & 0.1744 & 0.2694 & 0.3536 & 0.4918 \\
\hline Foreign Direct Investment & 0.0465 & 0.0058 & 0.1221 & -0.0287 & 0.1944 \\
\hline
\end{tabular}


Sustainability, Agri, Food and Environmental Research, (ISSN: 0719-3726), 10(X), 2022: http://dx.doi.org/

Table 4: Spearman's correlation coefficient for steel with Macroeconomic Indicators Spearman's correlation coefficient - STEEL

\begin{tabular}{lccccc}
\hline INDICATOR & 0-month lag & 1-month lag & 3-month lag & 6-month lag & 12-month lag \\
Construction Output & -0.2018 & -0.1656 & -0.1345 & 0.0566 & 0.0854 \\
Foreign Exchange Rate & 0.7213 & 0.6818 & 0.6472 & 0.4033 & -0.0389 \\
Inflation Rate & -0.2413 & -0.2612 & -0.1779 & -0.1513 & -0.2618 \\
Foreign Direct Investment & -0.0904 & -0.0613 & 0.1134 & 0.0584 & -0.0587
\end{tabular}

Checking for Multicollinearity: The main assumption while using some inputs to predict an output is that these inputs are independent variables that predict the output dependent variable. The existence of correlation between the independent variables is multicollinearity. Correlation coefficients were calculated in Microsoft Excel by finding the Variation Inflation Factor (VIF) which gives the severity of multicollinearity. Practical experience indicates that if any of the VIFs exceeds 5, there exists multicollinearity [6]. If it existed, certain variables are to be eliminated from the prediction models. Consumer Price Index shows VIF of 18.1942 with Housing utilities and Housing utilities a VIF of 10 with Producer Price Index respectively. Hence, Consumer Price Index and Housing utilities are removed as PPI has larger correlation coefficient. The remaining 4 indicators was then fit in an equation using stepwise regression.

Time Lag Selection: The major two criteria for selecting the time lag between the macroeconomic indicators and the output material prices will be the higher correlation coefficients changes per change in time lag and having enough time ahead for prediction [10]. For each indicator, correlation coefficients are calculated for each time lag of $0,1,3,6$, and 12 months. It is clearly seen that higher values of correlation coefficients are obtained when lagged for 6 months. The reliability of the prediction is directly related to the reliability of the independent variables. Hence, having enough time lag between the macroeconomic indicator and the material prices allows the collection of reliable macroeconomic indicators.

Step-wise Regression: Table 5 shows the result of fitting linear regression models by adding one indicator at a time (forward selection). The sole purpose of fitting linear regression here is not prediction, but rather reaching an indication on which independent variables can potentially be inputs to prediction models that utilize artificial neural networks (Shiha, A. Dorra, E.M. and Nassar, k. 2020). Adjusted coefficient of determination $\mathrm{R}^{2}$ and Akaike's information criterion will be used to judge the best combination of independent variables: highest adjusted $\mathrm{R}^{2}$ and lowest AIC shall be the selection criteria. 
Sustainability, Agri, Food and Environmental Research, (ISSN: 0719-3726), 10(X), 2022: http://dx.doi.org/

Table 5: Stepwise regression between macroeconomic indicators and prices using excel

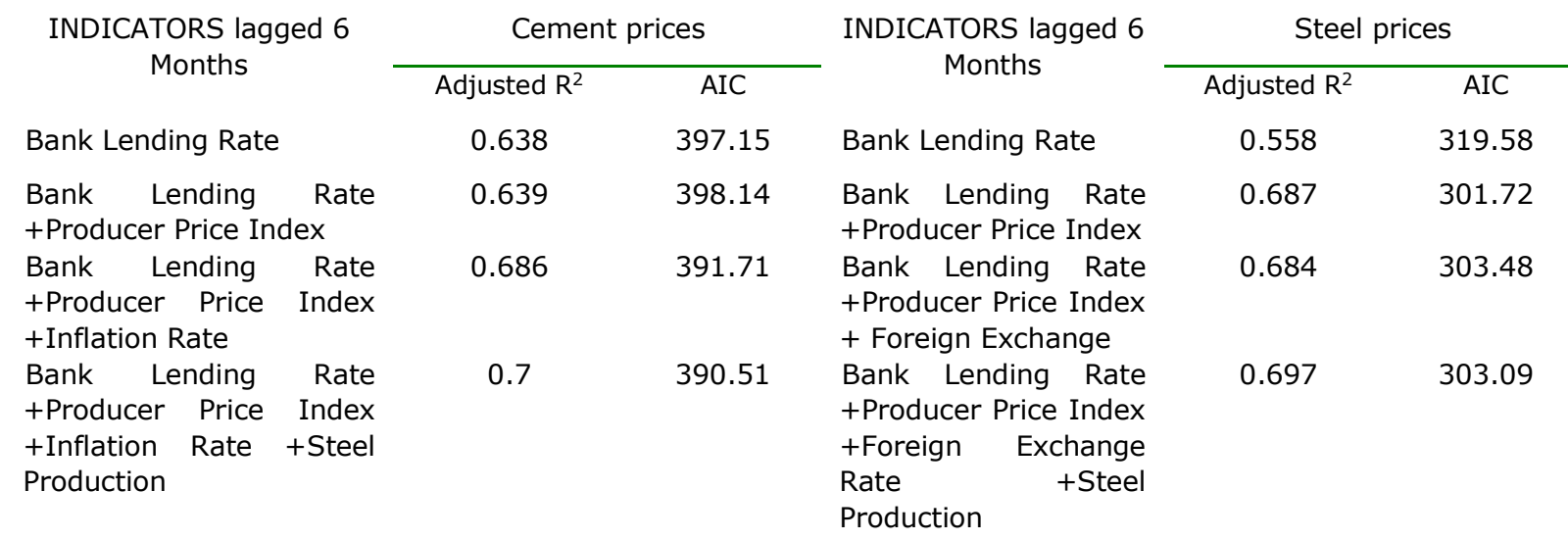

For prediction of steel prices, the highest adjusted $\mathrm{R}^{2}$ is the combination of all four independent variables and the lowest AIC is also the combination of all 4 independent variables: PPI, Bank Lending Rate, Steel Production and Inflation rate. Hence, the four macroeconomic indicators are used as inputs to the prediction models of cement and steel prices.

As conclusion, changes in the construction material cost have an impact on construction projects. Prediction of material prices can have a greater benefit to the contractor over their competitors when it comes to competing for projects as well as for timely completion. The research was done to identify the macroeconomic indicators of India which can act as potential inputs for predicting the prices of construction materials. To carryout this investigation, correlation analysis was done between the prices of materials and indicators followed by stepwise regression to fit the predictors to a model so as to indicate the significance of each predictors. Research identified four indicators out of nine indicators that can be useful for predicting construction material prices that shares high correlation with prices. Bank lending rate, producer price index, inflation rate and steel production are the identified indicators that is correlated with prices of cement and steel in India of which Producer Price Index shares the highest positive correlation with steel prices and bank lending rate with that of cement prices respectively. More indicators can be tested depending upon data availability, thus helping in more accurate predictions.

\section{ACKNOWLEDGEMENT}

Firstly, we give all honour and praise to God Almighty for giving us wisdom, strength, and patience for completion and submission of this paper. We would like to thank the Department of Civil Engineering of Toc $\mathrm{H}$ Institute of Science and Technology for all the help rendered. 
Sustainability, Agri, Food and Environmental Research, (ISSN: 0719-3726), 10(X), 2022:

http://dx.doi.org/

\section{REFERENCES}

Aithal, P. K., Dinesh. A. U., Geetha. M., Identifying Significant Macroeconomic Indicators for Indian Stock Markets, IEEE Explore, Vol 7, 143829-143840.

Asamoah. R.O., Baiden, B.K. and Nani, G. (2019), Towards the Establishment of Relationship between Macroeconomic Indicators and Cost of Public Educational Buildings in Ghana, Journal of Engineering, Vol. 2019 (11), 1-7.

Ashuri. B., Shahandashti, S. M. and J. Lu, (2012), Empirical tests for identifying leading indicators of ENR construction cost index, Construction Management and Economics, Vol.30, Issue 11, 917-927.

Asuero, A. G., Sayago, A., \& González, A. G (2006). The Correlation Coefficient: An Overview, Critical Reviews in Analytical Chemistry, Taylor and Francis, Vol 36(1), 41-59.

Chen. H.L. (2010), Using Financial and Macroeconomic Indicators to Forecast Sales of Large Development and Construction Firms, Journal of Real Estate Finance and Economics, Vol.40 (3), 310-331.

Daoud. J. L. (2017), Multicollinearity and Regression Analysis, Journal of Physics, Conference Series, 4th International Conference on Mathematical Applications in Engineering, Vol. 949.

Ernest. K., Theophilus. A. K., Amoah. P. and Emmanuel. B. B. (2019), Identifying key economic indicators influencing tender price index prediction in the building industry: A case study of Ghana, International Journal of Project Management, Vol.19 (2), 106-112.

Marzouk, M., and Amin, A., (2013), Predicting construction materials prices using fuzzy logic and neural networks, International Journal of Project Management, Vol.139 (9), 1190-1198.

Pewdum, W., Rujirayanyong, T. and Sooksatra, V., (2009), Forecasting final budget and duration of highway construction projects, International Journal of Project Management, Vol.16 (6), 544.

Shiha, A., Dorra, E.M., and Nassar, k., (2020), Neural Networks Model for Prediction of Construction Material Prices in Egypt Using Macroeconomic Indicators, Journal of Construction Engineering and Management, Vol. 146, (3):04020010

Xiao. C., J. Ye, R. M. Esteves, and C. Rong. (2016), Using Spearman's correlation coefficients for exploratory data analysis on big dataset, Concurrency Comput: Pract. Experience 28 (14), 3866-3878.

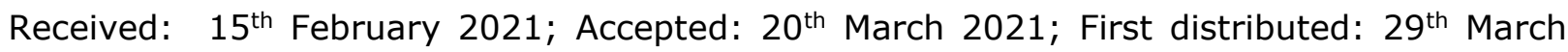
2021 